\title{
Rancangan dan Kinerja Teknis Mesin Parut Singkong Tipe Silinder Bertenaga Motor Bakar
}

\author{
Wilson Palelingan Aman"1), Darma ${ }^{2}$, Mathelda K. Roreng 3 , Sardi ${ }^{4}$ \\ 1,2) Program Studi Teknik Pertanian dan Biosistem Universitas Papua \\ 3) Program Studi Teknologi Hasil Pertanian Universitas Papua \\ 4) Alumni Program Studi Teknologi Hasil Pertanian Universitas Papua \\ *Email: w.palelingan@unipa.ac.id
}

DOI: http://dx.doi.org/10.21107/rekayasa.v12i1.5101

\begin{abstract}
ABSTRAK
Pemarutan merupakan salah satu tahapan penting dalam proses pengolahan tapioka. Untuk meningkatkan kapasitas produksi diperlukan mesin pemarut bertenaga motor. Bagian penting mesin pemarut singkong tipe silinder yang dapat mempengaruhi kinerja mesin adalah diameter gigi parut. Tujuan penelitian ini adalah merancang dan menguji kinerja mesin pemarut singkong tipe silinder dengan parameter pengamatan diameter gigi parut. Tahapan penelitian terdiri atas perancangan dan analisis fungsional mesin parut singkong. Perlakuan yang digunakan dalam penelitian ini adalah penggunaan 3 ukuran diameter gigi parut yang berbeda: 1,5 $\mathrm{mm}, 2 \mathrm{~mm}$ dan $3 \mathrm{~mm}$. Sedangkan parameter penelitian adalah kapasitas efektif, rendemen pati dan rendemen pati dalam ampas. Hasil penelitian menunjukkan bahwa penggunaan gigi parut berdiameter 1,5 $\mathrm{mm}$ menghasilkan kapasitas efektif dan rendemen pati tertinggi tertinggi dengan rendemen pati dalam ampas paling rendah. Kapasitas efektif tertinggi yang dihasilkan adalah sebesar $448,24 \mathrm{~kg} / \mathrm{jam}$ dengan rendemen pati $46,67 \%$. Sementara pati dalam ampas sebesar $10,73 \%$. Penggunaan gigi parut dengan diameter yang lebih besar, menghasilkan kapasitas dan rendemen pati yang lebih rendah.
\end{abstract}

Kata Kunci: Mesin Parut, Singkong, Diameter Gigi, Kinerja

\section{Design and Performance Analysis Cassava Grating Machine Cylinder-Type Powered by Combustion Engine} ABSTRACT

The grating is one of the important stages in processing tapioca. To increase production capacity, a grating machine powered by the engine is needed. The important part of cassava grating machine that can affect the engine performance is the diameter of grater teeth. The purpose of this study was to design and test the performance of cylindrical type cassava grater machines with the observed parameters of the diameter of the grater teeth. The stages of the study consisted of the design and then the functional analysis of cassava grating machines. The treatment used in this study was the use of 3 different sizes of grated tooth diameters: $1.5 \mathrm{~mm}, 2 \mathrm{~mm}$ and $3 \mathrm{~mm}$. While the research parameters are effective capacity, starch yield, and yield of starch in the pulp. The results showed that the using of a $1.5 \mathrm{~mm}$ diameter solution produced the highest effective capacity and highest yield of starch with the lowest yield of starch in the pulp. The highest effective capacity produced was $448.24 \mathrm{~kg} /$ hour with a starch yield of $46.67 \%$. While starch in pulp is $10.73 \%$. The use of grater teeth with a larger diameter results in lower starch capacity and yield. Keywords: Grating Machine, Cassava, Teeth Diameter, Performance

\section{PENDAHULUAN}

Proses produksi Tapioka kering umumnya terdiri atas beberapa tahap operasi : pencucian, pengupasan kulit, pemarutan, ekstraksi, pengendapan, pengeringan serta penggilingan tapioka kering. Dari berbagai tahapan operasi tersebut, salah satu yang paling penting ada-

\footnotetext{
Article History:

Received: Maret 2019; Accepted: April 2019

ISSN: 2502-5325 (Online) Terakreditasi Peringkat 4 oleh

Kementerian Riset, Teknologi dan Pendidikan Tinggi (ARJUNA) berdasarkan Keputusan Direktur Jenderal Penguatan Riset dan Pengembangan Nomor: 21/E/KPT/2018 tanggal 9 Juli 2018
}

lah pemarutan yang merupakan pemisahan secara mekanis dari didnding sel dan pengeluaran granula pati menggunakan air. Proses ini dapat dilakukan secara manual atau menggunakan mesin, tergantung pada kapasitas keluaran yang dibutuhkan (Sajeev et al. 2012). Pemarutan merupakan aktivitas pengecilan ukuran, yang menyebabkan kerusakan dinding sel dari umbi singkong menjadi partikel

\section{Cite this as:}

Aman, W., Darma, D., Roreng, M., \& Sardi, S. (2019). Rancangan dan Kinerja Teknis Mesin Parut Singkong Tipe Silinder Bertenaga Motor Bakar. Rekayasa, 12(1), 59-65. doi:http://dx. doi.org/10.21107/rekayasa.v12i1.5101

(C) 2019 Universitas Trunojoyo Madura 
yang lebih kecil (Igoni et al. 2016). Mekanisme yang umumnya dipakai untuk proses pemarutan ada dua macam. Pertama adalah menggunakan parut berputar. Pada proses pemarutan ini, ketela pohon yang telah dikupas diparut dengan menggunakan silinder berparut, yang mendesak pada celah dengan jarak tertentu. Silinder berparut diputar dengan menggunakan motor pada kecepatan putar tertentu. Sistem ini dipakai pada proses pemarutan mekanis. Sedangkan yang kedua menggunakan pemarut manual atau pemarut tetap. Pada proses pemarutan ini, pemarutan menggunakan plat yang terbuat dari stainless steel, yang memiliki gigi parut yang berbentuk seperti paku tajam. Gigi parut ini akan menyayat ketela pohon sehingga menjadi butiran/ sayatan yang halus (Soegihardjo et al., 2005). Bagian fungsional dari alat atau mesin pemarut adalah silinder pemarut yang terdiri dari sejumlah gigi pemarut berdiameter berbeda. Bagian tersebut akan berpengaruh terhadap hasil pemarutan. Kerusakan dinding sel akibat penggunaan gigi parut terhadap berbagai produk seperti singkong dan sagu dilaporkan di berbagai hasil penelitian. Balagopalan et al. (2002) menjelaskan proses pemarutan dengan penggunaan sejumlah gigi yang tajam pada permukaan pemarut menyebabkan dinding sel menjadi sobek dan umbi akan menjadi halus tetapi tidak semua granula pati dapat dilepaskan. Nanda et al. (2004) mengembangkan alat pemarut primer dengan bilah gigi gergaji untuk ekstraksi tapioka. Penggunaan mata parut juga dilakukan ada pemarutan empulur sagu sebelum diekstrak (Darma, 2011; Hermanto et al., 2011; Thoriq et al., 2017). Pengaruh perbedaan dimensi gigi pemarut tersebut diduga ada kesamaan pada proses pemarutan empulur sagu dengan umbi singkong. Namun demikian, hubungan antara dimensi serta susunan gigi silinder pemarut untuk umbi singkong tidak dapat dijelaskan melalui proses pemarutan empulur sagu karena perbedaan secara fisik antara keduanya.
Penelitian ini dilakukan dengan merancang mesin pemarut singkong yang dilengkapi dengan penggiling pati kering. Ruang lingkup penelitian adalah penggunaan ukuran diameter gigi parut yang berbeda-beda yang bertujuan untuk mengetahui pengaruh perbedaan ukuran tersebut terhadap kinerja mesin dalam pemarutan umbi singkong.

\section{METODE PENELITIAN}

Penelitian ini dilakukan dalam beberapa tahap, yaitu : Perancangan mesin parut singkong, analisis fungsional dan kinerja mesin.

\section{Perancangan Mesin Parut Singkong}

Bahan yang digunakan untuk membuat mesin pemarut singkong adalah besi siku berukuran $4 \mathrm{~cm} \times 4 \mathrm{~cm} \times 0,2 \mathrm{~cm}$, besi plat dengan ketebalan $2 \mathrm{~mm}$, silinder kayu Nangka berdiameter $12 \mathrm{~cm}$ dengan panjang $15 \mathrm{~cm}$, kawat stainless steel berdiameter $1,5 \mathrm{~mm}, 2 \mathrm{~mm}$ dan 3 $\mathrm{mm}$, besi As stainless steel berdiameter 2,54 $\mathrm{cm}$, pulley, v-belt, motor bakar 5,5 HP, mur, baut, ring, cat, gemuk, umbi singkong sebanyak 72 kg, kain saring dan air.

Mesin pemarut singkong yang dirancang ditujukan untuk dapat mengerjakan 2 tahapan proses pengolahan singkong sekaligus yaitu pemarutan dan penggilingan tapioka kering. Namun demikian analisis yang dilakukan dalam penelitian ini hanya terhadap proses pemarutan. Hasil rancangan mesin pemarut Tapioka tipe silinder disajikan melalui Gambar 1.

\section{Analisis Fungsional dan Kinerja Mesin Parut}

Analisis fungsional mesin pemarut singkong ini dilakukan melalui pengujian kinerja alat dengan perlakuan utama gigi dengan diameter gigi parut berukuran $1,5 \mathrm{~mm}, 2 \mathrm{~mm}$ dan $3 \mathrm{~mm}$ pada kecepatan putar silinder yang sama. Perlakuan Bahan yang digunakan pada pengujian kinerja berupa umbi singkong masing-masing sebanyak $8 \mathrm{~kg}$ untuk setiap per-

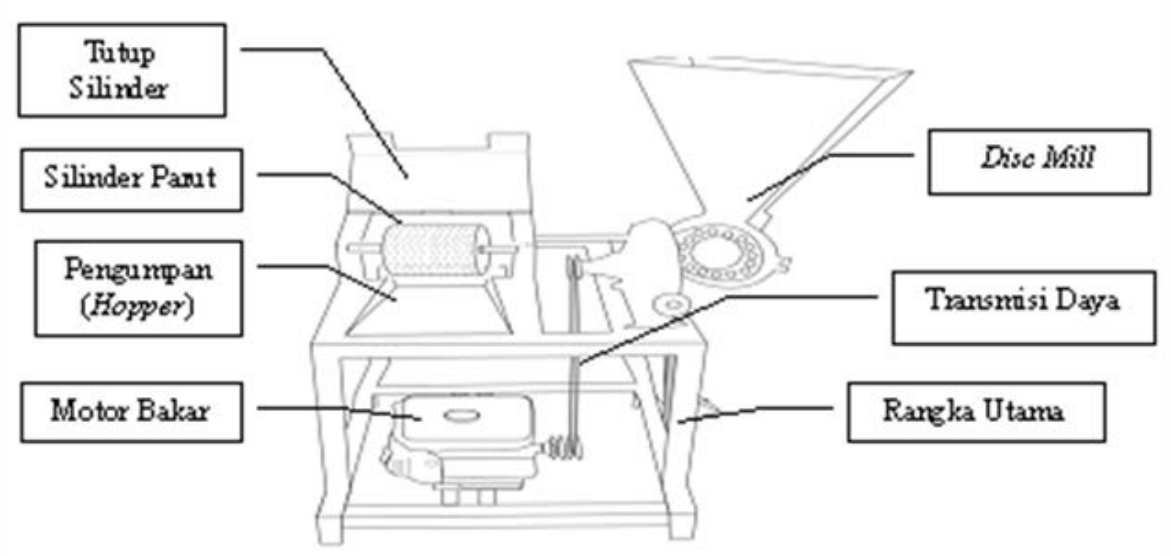

Gambar 1. Rancangan Mesin Parut Singkong Bertenaga Motor Bakar 


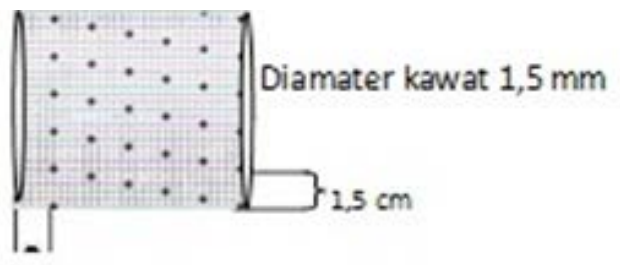

$1,5 \mathrm{~cm}$

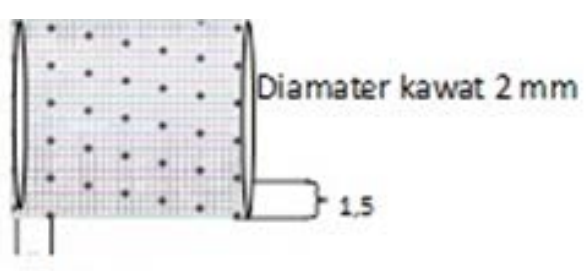

1,5

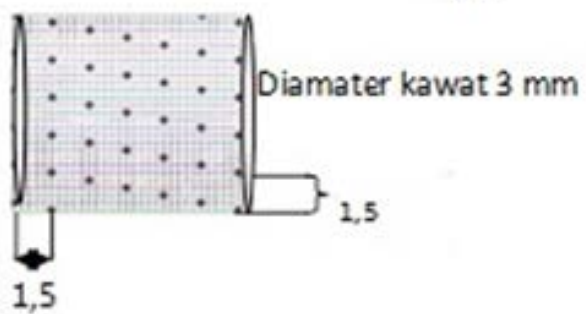

Gambar 2. Susunan Gigi pada Silinder Pemarut

lakuan dengan masing-masing 3 kali ulangan. Parameter pengujian meliputi kapasitas efektif pemarut, rendemen pati dalam hasil parutan dan rendemen pati dalam ampas. Susunan gigi parut pada silinder disajikan pada Gambar 2.

Tahapan pengujian kinerja mesin pemarut singkong adalah sebagai berikut:

1. Persiapan bahan dan alat dan bahan yang diperlukan antara lain umbi singkong, timbangan, stop watch, ember dan air.

2. Pengupasan dan pencucian umbi singkong

3. Penimbangan umbi singkong masing-masing $8 \mathrm{~kg}$ untuk 3 perlakuan dengan 3 kali ulangan.

4. Hasil pemarutan ditimbang dan diambil sebanyak $2 \mathrm{~kg}$ untuk setiap ulangan, kemudian diekstrak dengan air mengalir dan diperas hingga air perasan jernih.

5. Hasil Perasan (starch milk) diendapkan selama 19 jam.

6. Penimbangan pati hasil ekstraksi.

7. Penimbangan ampas hasil ekstraksi sebanyak 0,5 kg untuk masing-masing ulangan.

8. Penghancuran ampas dengan menggunakan alat Blender, kemudian diekstrak menggunakan air mengalir dan diperas hingga air perasan jernih.

9. Hasil perasan (starch milk) diendapkan selama 19 jam.

10. Penimbangan pati yang dihasilkan.

Parameter pengujian kinerja yang digunakan dalam penelitian ini adalah sebagai berikut:

\section{Kapasitas Efektif Pemarut (kg/jam)}

Kapasitas efektif pemarut dihitung dengan menimbang secara langsung umbi singkong yang sudah dikupas $(\mathrm{kg})$ dibagi dengan waktu yang dibutuhkan selama pemarutan (jam), yang dinyatakan melalui Persamaan (1).

$$
\mathrm{KE}=(\mathrm{ms}) /(\mathrm{t})
$$

\author{
Keterangan : \\ KE :Kapasitas efektif pemarut $(\mathrm{kg} / \mathrm{jam})$ \\ $\mathrm{ms}$ :Massa hasil pemarutan umbi singkong \\ $(\mathrm{kg})$ \\ t :Waktu (jam)
}

2. Rendemen Pati dalam hasil Parutan (\%)

Rendemen pati terhadap hasil parutan umbi singkong dihitung dengan menimbang hasil parutan umbi singkong sebanyak $2 \mathrm{~kg}$, kemudian diekstrak dengan air mengalir, diremas-remas dan diperas berkali-kali sampai air hasil perasan jernih. Hasil perasan (starch milk) diendapkan selama 19 jam, lalu pati yang diperoleh kemudian dibagi dengan massa umbi yang diparut $(\mathrm{kg})$. Rendemen pati dalam parutan dihitung dengan menggunakan Persamaan (2).

Dimana:

$$
\text { Rendemen }=\mathrm{mp} / \mathrm{ms} \times 100 \%
$$

Rendemen : Rendemen pati dalam hasil parutan (\%)

$\mathrm{mp} \quad$ : Massa pati umbi singkong $(\mathrm{kg})$

ms : Massa hasil parutan umbi singkong $(\mathrm{kg})$

\section{Rendemen Pati dalam Ampas (\%)}

Rendemen pari dalam ampas dihitung dengan menimbang ampas yang sudah diekstrak sebanyak $0,5 \mathrm{~kg}$, lalu diblender sampai halus dan diekstrak dengan menggunakan air mengalir, diperas berkali-kali sampai air hasil perasan jernih. Hasil perasan diendapkan selama 19 jam untuk mendapatkan pati. Pati yang dihasilkan kemudian dibagi dengan ampas sebelum diekstak lalu dikalikan dengan $100 \%$. Rendemen pati dalam ampas dihitung dengan Persamaan (3).

$$
\mathrm{RPA}=\mathrm{mp} / \mathrm{ma} \times 100 \%
$$

Keterangan:

RPA : rendemen pati dalam ampas (\%)

$\mathrm{mp}$ : Massa pati (kg)

ma : Massa ampas yang sudah diekstrak $(\mathrm{kg})$ 


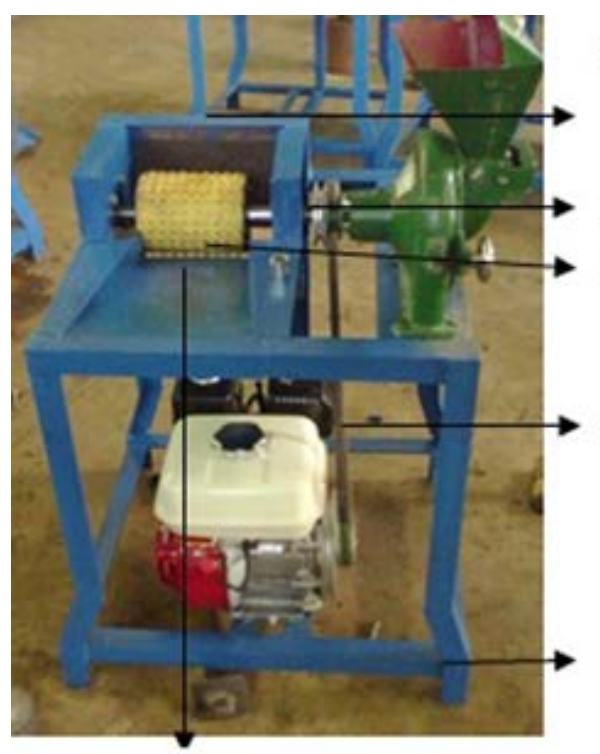

Hopper penepung
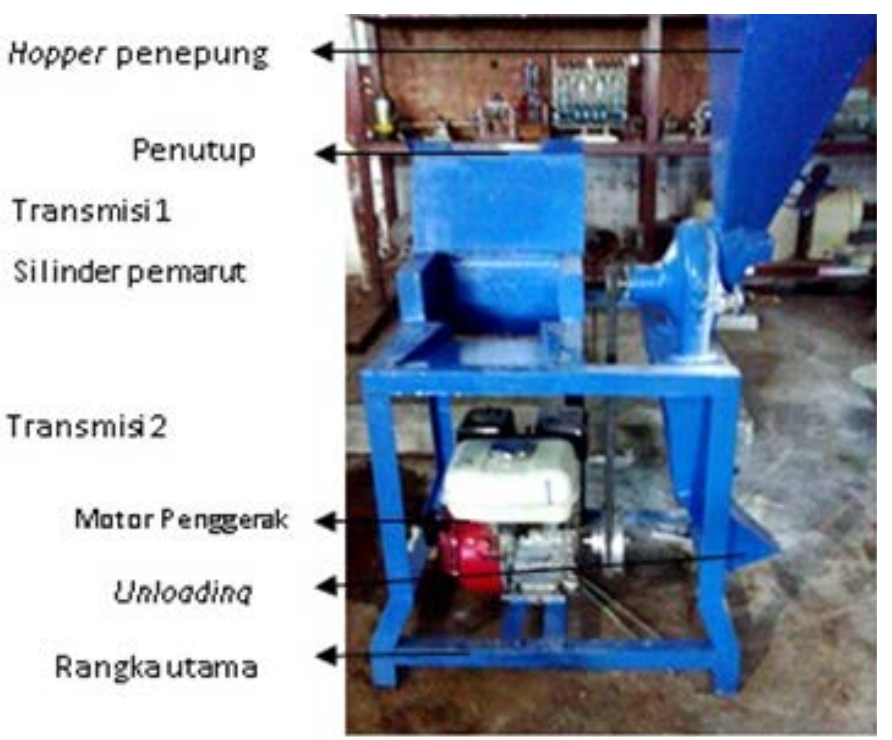

Hopper pemarut

Transmisi2

Motor Penggerak

Unloading

Rangka utama

Gambar 3. Konstruksi Mesin Pemarut dan Penepung Singkong Bertenaga Motor Bakar

\section{HASIL DAN PEMBAHASAN}

\section{Konstruksi Mesin Pemarut Singkong}

Rancang bangun alat pemarut dan penepung singkong terdiri dari 6 bagian utama yaitu: 1) rangka utama, 2) motor penggerak, 3) sistem transmisi, 4) bagian pengumpan (hopper), 5) silinder pemarut dan 6) bagian pengeluaraan (unloading). Hasil konstruksi mesin pemarut singkong yang dihasilkan dari penelitian ini disajikan melalui Gambar 3.

\section{Penepung Singkong Bertenaga Motor Bakar} Rangka utama berfungsi untuk mendukung dan sekaligus merupakan dudukan dari silinder pemarut, penepung, motor penggerak dan bagian-bagian yang lainnya. Karena fungsi tersebut dalam rangka utama dirancang yang lebih kuat beban dan getaran selama mesin beroperasi. Rangka utama terbuat dari besi siku berukuran $4 \mathrm{~cm} \times 4 \mathrm{~cm} \times 0,2 \mathrm{~cm}$. Mesin digerakkan oleh motor penggerak berfungsi sebagai sumber tenaga untuk menggerakkan silinder pemarut dan penepung singkong. Motor penggerak yang digunakan mempunyai daya sebesar $5,5 \mathrm{HP}$ atau setara dengan $4,103 \mathrm{~kW}$.

Sistem transmisi yang digunakan pada alat ini adalah pulley dan sabuk ( $v$-belt). Sistem transmisi berfungsi untuk menyalurkan daya yang dihasilkan oleh sumber tenaga penggerak sehingga dapat memutar silinder pemarut dan penepung singkong.

Bagian pengumpan pemarut singkong (hopper) yang berfungsi sebagai tempat untuk pemasukan/pegumpanan umbi singkong ke bagian silinder pemarut. Bagian ini terbuat dari plat besi dengan tebal $2 \mathrm{~mm}$, yang terdapat pada bagian atas, bawah serta samping kanan dan kiri. Pada bagian atas hopper diberi engsel sebagai pintu, sedangkan pada bagian bawah sebagai penahan yang membantu bergesernya umbi pada saat pemarutan. Bagian depan hopper dibuat miring sehingga memudahkan pendorong umbi singkong. Pendorongan ini memungkinkan potongan-potongan kecil umbi singkong yang ikut terparut.

Silinder pemarut merupakan salah satu bentuk operasi pengecilan ukuran dengan cara pemotongan dan peremukan (cutting and crushing). Tujuan proses pemarutan untuk merusak dinding sel serta partikel-partikel sel sehingga pati yang terdapat di dalam sel bisa terekstrak. Silinder pemarut yang digunakan dalam penelitian ini terbuat dari kayu dengan diameter $12 \mathrm{~cm}$ dan panjang $15 \mathrm{~cm}$. Silinder pemarut dilengkapi dengan kawat stainless steel yang berdiameter $1,5 \mathrm{~mm}, 2 \mathrm{~mm}$ dan 3 $\mathrm{mm}$, berfungsi sebagai gigi parut, yang dipasang dengan cara ditancapkan pada permukaan silinder sebanyak 240 buah. Tinggi gigi parut adalah $0,5 \mathrm{~cm}$ dari permukaan silinder dengan jarak horisontal dan vertikal antar gigi parut sebesar 1,5 cm (Gambar 4).

Bagian pengeluaraan (unloading) berfungsi sebagai penyaluran hasil parutan ke tempat penampungan. Bagian penyaluran terbuat dari besi plat dengan kemiringan tertentu yang memungkinkan hasil parutan mengalir. Spesifikasi rancangan pemarut singkong yang dihasilkan pada penelitian ini dapat dilihat pada Tabel 1. 

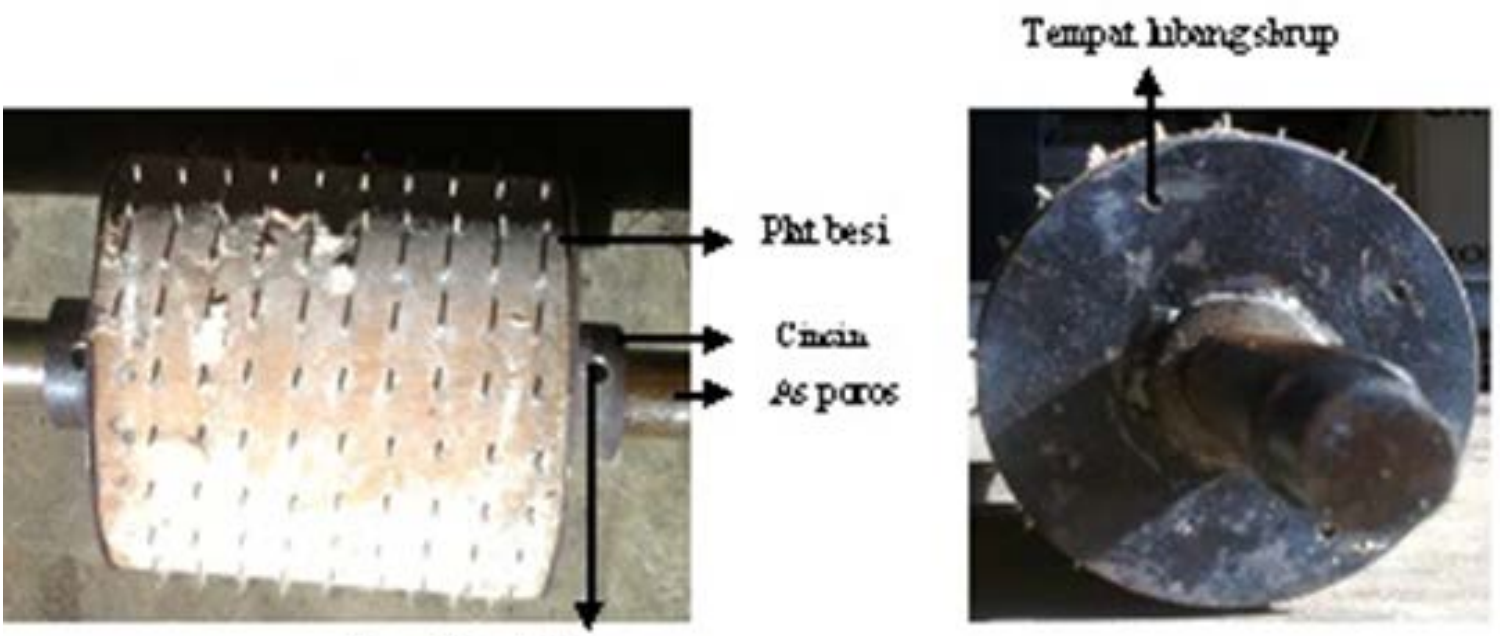

Tempat bourt 12

Gambar 4. Silinder Pemarut Singkong

Tabel 1. Spesifikasi Rancangan Mesin Pemarut Singkong

\begin{tabular}{|c|c|c|}
\hline No & Parameter & Spesifikasi \\
\hline 1 & Rangka (frame) & $\begin{array}{l}\text { Besi siku Ukuran : } 4 \mathrm{~cm} \times 4 \mathrm{~cm} \times 0,2 \mathrm{~cm} \\
\text { Besi Plat tebal : } 2 \mathrm{~mm} \\
\text { Panjang: }: 70 \mathrm{~cm} \\
\text { Lebar }: 54 \mathrm{~cm} \\
\text { Tinggi }: 75 \mathrm{~cm}\end{array}$ \\
\hline 2 & $\begin{array}{l}\text { Sumber tenaga } \\
\text { penggerak }\end{array}$ & Motor Bakar 4 Tak 5,5 HP \\
\hline 3 & $\begin{array}{l}\text { Sistem } \\
\text { transmisi }\end{array}$ & Pulley dan v-belt \\
\hline 4 & $\begin{array}{l}\text { Pengumpan } \\
\text { (hopper) }\end{array}$ & $\begin{array}{l}\text { Besi Plat tebal : } 2 \mathrm{~mm} \\
\text { Panjang : }: 31,5 \mathrm{~cm} \\
\text { Lebar }: 23,5 \mathrm{~cm} \\
\text { Tinggi }: 19 \mathrm{~cm}\end{array}$ \\
\hline 5 & $\begin{array}{l}\text { Silinder } \\
\text { pemarut }\end{array}$ & $\begin{array}{l}\text { Kayu nangka Panjang } 15 \mathrm{~cm}, \varnothing 12 \\
\text { Diameter Gigi: } 1,5 \mathrm{~mm}, 2 \mathrm{~mm} \text { dan } 3 \mathrm{~mm} \\
\text { Piringan selinder } 12 \mathrm{cmm} \\
\text { Berat silinder Gigi } 1,5 \mathrm{~mm}: 1,055 \mathrm{~kg} \\
\text { Berat silinder Gigi } 2 \mathrm{~mm} \quad: 1,220 \mathrm{~kg} \\
\text { Berat silinder Gigi } 3 \mathrm{~mm} \quad: 1,275 \mathrm{~kg}\end{array}$ \\
\hline 6 & $\begin{array}{l}\text { Bagian } \\
\text { pengeluaran } \\
\text { (unloading) }\end{array}$ & $\begin{array}{l}\text { Besi Plat tebal : } 2 \mathrm{~mm} \\
\text { Panjang : } 20 \mathrm{~cm} \\
\text { Lebar }: 23,7 \mathrm{~cm}\end{array}$ \\
\hline 7 & $\begin{array}{l}\text { Berat mesin } \\
\text { pemarut }\end{array}$ & $60 \mathrm{~kg}$ \\
\hline
\end{tabular}

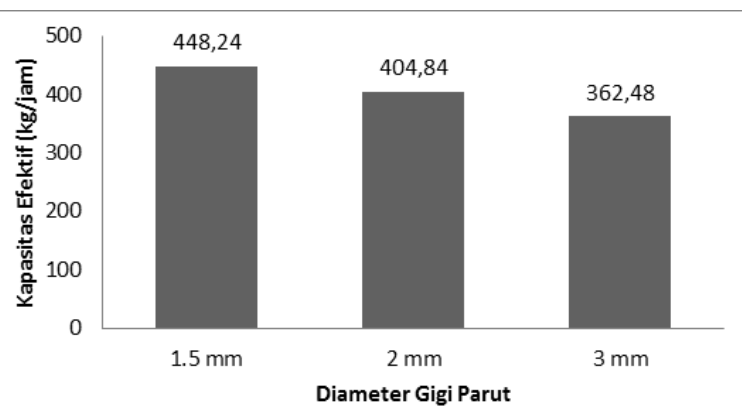

Gambar 5. Kapasitas Efektif Alat dan Mesin Pemarut umbi Singkong

\section{Analisis Fungsional dan Kinerja Mesin Parut}

Analisis fungsional mesin dilakukan melalui pengujian kinerja mesin pada 3 perlakuan diameter gigi parut yang berbeda. Parameter uji kinerja mesin parut adalah kapasitas efektif pemarutan, rendemen pati terhadap hasil parutan dan rendemen pati dalam ampas.

\section{Kapasitas Efektif Pemarutan}

Kapasitas efektif pemarutan adalah kemampuan alat untuk memarut sejumlah umbi singkong dalam waktu tertentu yang dinyatakan dalam satuan $\mathrm{kg} / \mathrm{jam}$. Kapasitas efektif pemarut singkong dihitung dengan menimbang umbi singkong yang telah dikupas untuk diparut yaitu sebanyak $8 \mathrm{~kg}$ per ulangan. Kemudian dibagi dengan waktu yang dibutuhkan untuk memarut umbi. Gambar 5 menunjukkan kapasitas efektif pemarutan pada diameter gigi yang berbeda-beda.

Hasil penelitian terhadap kapasitas efektif alat dan mesin pemarut (Gambar 5) menunjukkan bahwa penggunaan gigi parut dengan diameter $1,5 \mathrm{~mm}$ menghasilkan kapasitas efektif pemarut tertinggi yaitu sebesar $448,24 \mathrm{~kg} /$ jam. Penggunaan gigi parut berdiameter 2 $\mathrm{mm}$ menghasilkan kapasitas efektif pemarut tertinggi berikutnya yaitu sebesar $404,48 \mathrm{~kg} /$ jam. Sedangkan kapasitas efektif pemarut terendah diperoleh pada penggunaan gigi parut berdiameter $3 \mathrm{~mm}$ yaitu sebesar $362,48 \mathrm{~kg} /$ jam. Data hasil pengukuran tersebut menunjukkan bahwa semakin kecil diameter gigi parut maka kapasitas efektif pemarut yang dihasilkan semakin tinggi.

Pola hubungan antara kapasitas efektif dengan diameter gigi parut tersebut diduga terjadi karena penggunaan diameter gigi parut yang lebih kecil akan menghasilkan luas per- 
mukaan pemarutan yang lebih besar. Dengan kata lain ukuran granula hasil parutan umbi singkong akan semakin kecil dengan penggunaan diameter gigi parut yang kecil pula. Hal tersebut sejalan dengan pendapat Fellows (1992) yang menyatakan bahwa dalam pengolahan pangan, pengecilan ukuran dapat menyebabkan peningkatan rasio luas permukaan terhadap volume bahan pangan yang dapat meningkatkan laju pengeringan, pemanasan dan pendinginan serta meningkatkan efesiensi dan laju ekstraksi dari komponen liquid bahan pangan tersebut.

Kapasitas efektif mesin pemarut umbi singkong hasil penelitian ini hampir sama dengan dengan mesin parut singkong yang dikembangkan oleh Nanda et al. (2004), yang mempunyai kapasitas berkisar $360-385$ kg/ jam, lebih tinggi dibandingkan dengan mesin parut singkong yang digerakkan dengan pedal dengan kapasitas 58,59 kg/jam (Tambari et al. 2014), tetapi lebih rendah dari kapasitas mesin parut dengan silinder ganda yang digerakkan dengan motor listrik dengan kapasitas berkapasitas 730,58 kg/jam (Oriaku et al. 2015). Untuk mesin parut sagu tipe silinder bertenaga motor bakar, kapasitas efektif hasil penelitian bervariasi dari berbagai hasil penelitian seperti Ratnaningsih et al. (2010) sebesar $268,43 \mathrm{~kg} / \mathrm{jam}$, Reniana et al.(2017) sebesar $322,52 \mathrm{~kg} / \mathrm{jam}$ dan Thoriq et al. (2017) sebesar 649,38 sebesar. Perbedaan tersebut karena sifat fisik antara umbi singkong dengan empulur sagu dan karakteristik operasi mesin parut yang digunakan khususnya gigi silinder pemarut serta kecepatan putar silinder.

Proses pemarutan merupakan salah satu bentuk dari operasi pemotongan (cutting) yang membutuhkan sejumlah besar energi. Kebutuhan energi dalam proses pemotongan dipengaruhi oleh sejumlah faktor, seperti sifat mekanis bahan, geometri dan bentuk tepi pemotong, serta kondisi kinematik Sifat-sifat mekanis bahan bergantung pada jenis bahan, yang dipengaruhi oleh tahap pertumbuhan dan kadar air, lokasi pemotongan, dan lainlain (Sitkei, 1986).

\section{Rendemen Pati dalam Hasil Parutan}

Rendemen pati dalam hasil parutan adalah persentase pati yang terdapat dalam hasil parutan umbi singkong. Rendemen pati dalam hasil parutan pada penelitian ini ditentukan dengan menimbang hasil parutan sebanyak yaitu $2 \mathrm{~kg}$ kemudian diektraksi untuk mendapatkan pati hasil endapan. Pati yang diperoleh, kemudian ditimbang dan dibagi massa hasil parutan tersebut. Perbandingan antara massa pati yang didapat dibagi massa hasil parutan $2 \mathrm{~kg}$ dikalikan $100 \%$ untuk

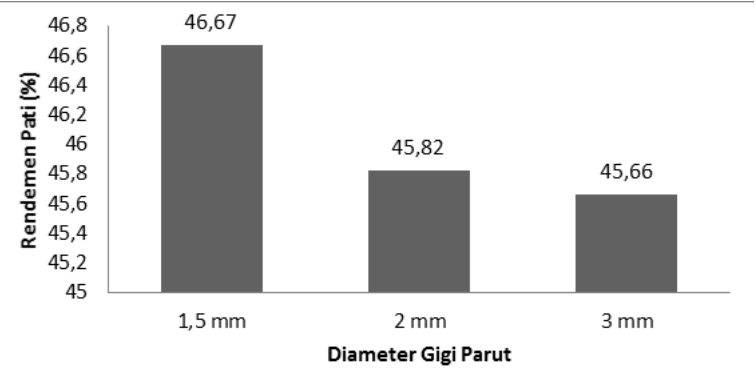

Gambar 6. Rendemen Pati dalam Hasil Parutan

mendapatkan rendemen pati dalam hasil parutan. Hasil pengukuran rendemen pati basah yang dihasilkan tersaji pada Gambar 6.

Gambar 6 menunjukkan bahwa penggunaan gigi parut dengan diameter $1,5 \mathrm{~mm}$ menghasilkan rendemen pati dalam hasil pemarut yang tertinggi yaitu sebesar $46,67 \%$. Rendemen pati tertinggi berikutnya yaitu sebesar $45,82 \%$, yang diperoleh dengan penggunaan gigi parut berdiameter $2 \mathrm{~mm}$. Sedangkan rendemen pati dalam hasil parutan terendah diperoleh pada penggunaan gigi parut yang diameter $3 \mathrm{~mm}$ yaitu sebesar $45,55 \%$. Data hasil penelitian tersebut menunjukan bahwa semakin kecil diameter gigi parut maka rendemen pati yang dihasilkan semakin tinggi.

Model hubungan antara diameter gigi parut dengan rendemen pati tersebut, terjadi karena semakin kecil diameter gigi parut akan menyebabkan ukuran granula hasil parutan umbi singkong akan semakin kecil atau semakin halus. Hal tersebut berarti terjadi kerusakan dinding sel umbi yang semakin besar, akibatnya pati yang tersimpan dalam sel tersebut akan semakin mudah dikeluarkan melalui proses ekstraksi. Dengan kata lain, penggunaan diameter gigi parut yang semakin besar akan menghasilkan ukuran granula parutan yang semakin besar pula, yang menyebabkan pati yang tersimpan dalam sel lebih sulit diekstrak. Sehingga rendemen pati yang dihasilkan akan lebih rendah.

Rendemen pati dalam hasil parutan singkong yang diperoleh melalui hasil penelitian ini lebih tinggi dengan hasil beberapa hasil penelitian sebelumnya. Perbandingan penelitian dengan yang lain tentang rendemen pati singkong hasil parutan antara lain menurut Thaib (1985) rendemen tapioka berkisar antara 1924\%. Selain faktor teknik pengolahan (alat dan mesin) yang digunakan, rendemen pati singkong juga dipengaruhi oleh faktor umur panen yang optimum. Umur panen sebelum dan sesudah umur panen optimum dapat menyebabkan kehilangan sejumlah kadar pati dalam umbi singkong (Barret et al. 1985). 


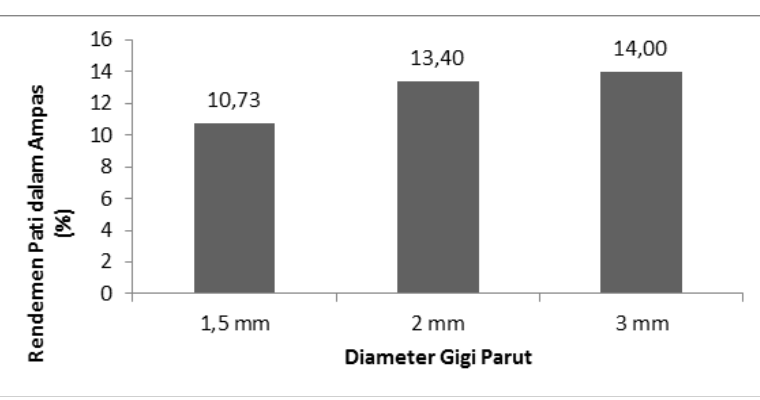

Gambar 7. Rendemen Pati dalam Ampas

\section{Rendemen Pati dalam Ampas}

Rendemen pati dalam ampas adalah persentase pati yang terdapat di dalam ampas. Rendemen pati dalam ampas pada penelitian ini ditentukan dengan menimbang hasil ektraksi parutan ampas yaitu 0,5 kg kemudian diblender sampai halus untuk mendapatkan pati. Rendemen pati dalam ampas merupakan perbandingan antara massa pati yang dihasilkan dibagi ampas hasil parutan dikalikan $100 \%$

Hasil pengukuran rendemen pati dalam ampas umbi singkong (Gambar 7), menunjukkan bahwa penggunaan gigi pemarut diameter 3 $\mathrm{mm}$ menghasilkan rendemen ampas tertinggi yaitu sebesar 14,00\%. Penggunaan gigi pemarut yang berdiameter $2 \mathrm{~mm}$ menghasilkan rendemen pati dalam ampas tertinggi kedua yaitu sebesar $13,40 \%$. Sedangkan rendemen pati dalam ampas terendah diperoleh pada penggunaan gigi pemarut yang berdiameter $1 \mathrm{~mm}$ yaitu sebesar 10,73\%. Data hasil penelitian tersebut menunujukan rendemen pati dalam ampas bahwa berbanding lurus diameter gigi parut. Namun jika dibandingkan dengan rendemen pati hasil parutan, pada masing-masing diameter gigi parut yang sama, kedua rendemen tersebut berbanding terbalik Hubungan antara diameter gigi pemarut dengan rendemen pati dalam ampas yang berbanding lurus, terjadi karena diameter gigi pemarut yang lebih besar akan menghasilkan ukuran granula umbi hasil parutan yang lebih besar. Akibatnya akan lebih banyak pati yang tertinggal dalam granula umbi singkong dalam hasil parutan sehingga jika diekstrak hanya sebagian pati saja yang terekstrak.

\section{SIMPULAN}

Berdasarkan hasil penelitian dapat disimpulkan bahwa mesin pemarut singkong yang dihasilkan mempunyai kapasitas efektif pemarutan tertinggi 448,24 $\mathrm{kg} / \mathrm{jam}$ dengan rendemen $46,67 \%$. Kapasitas efektif dan rendemen pati tertinggi diperoleh melalui penggunaan diameter gigi parut sebesar 1,5 $\mathrm{mm}$.

\section{DAFTAR PUSTAKA}

Balagopala, C. 2002. Cassava Utilitation in Food, Feed and Industri, in Hillocks, R.J., J.M. Thresh, A.C. Bellotti (Eds.). Cassava: Biology, Production and Utilization. CAB International. New York. P 301-318.

Barret, D.M. and D.S. Damardjati. 1985. Quality Improvement of Cassava Yield in Indonesia. Journal Penelitian dan Pengembangan Pertanian Vol.3 (2): 40-48.

Darma, 2011. Variant-I mesin pemarut sagu tipe silinder bertenaga motor bakar. Jurnal Agrotek 2(3): 80-88.

Fellows. P., 1992. Food Processing Technology Principles and Practice. Singapure.

Hermanto, Ansharullah, A. Nuwiyah dan Muhidin. Perbedaan Teknik Pemarutan dan Pengaruhnya Terhadap Peningkatan Rendemen dan Mutu Tepung Sagu. Agriplus Vol. 21 (1):30-35.

Igoni, A.H. dan I.F. Manuel. 2016. Size Dependence of Energy Required For Cassava Grating. Energy and Environment Research; Vol. 6 (2):1-9.

Nanda, S.K., P. Hemasankari dan J.T. Sheriff. 2004. Development of a primary rasperfor starch extraction from tuber crops. Proceedings of National Seminar: Root and Tuber Crops (NSRTC I), Orissa India, October 29-31,2004.

Oriaku, E.C., C.N. Agulanna, E.N.' Ossai, J.O. Odenigbo dan U.L. Adizue. 2015. Design and Performance Evaluation of a Double Action Cassava Grating Machine. Journal of Emerging Trends in Engineering and Applied Sciences (JETEAS) Vol.6 (3):196-203.

Ratnaningsih, N. Setyawan, K.T. Dewandari dan D. Sumangat. 2010. Rekayasa Alat Pemarut Sagu Tipe Silinder. Jurnal Enjiniring Pertanian Vol.8 (1):67-74.

Reniana, Darma dan A. Kurniawan. 2017. Prototipe Mesin Parut Empulur Sagu Tipe Silinder Bertenaga Motor Bakar. Jurnal Teknik Pertanian Lampung Vol. 6 (2):89-94.

Sajeev, M.S., S.K. Nanda and J.T. Sheriff. 2012. An Efficient Blade Type Rasper for Cassava Starch Extraction. Journal of Root Crops Vol.38 (2):151-156.

Sitkei, G. 1986. Depvelopments in Agricultural Engineering. Mechanics of Agricultural Materials. Asterdam, New York.

Soegihardjo, O dan Aninditya. 2005. Perancangan Mesin Pembuat Tepung Tapioka. Jurnal Teknik Mesin Vol.7 (2):22-27.

Tambari, S., I. Benjamin, K. Sorbari, O.W. Daibi dan O. Datonye. 2014. Design Analysis of a Pedal Powered Cassava Grinding Machine. IOSR Journal of Mechanical and Civil Engineering Vol.11 (5):34-43.

Thaib, A. 1985. Bimbingan Pembuatan Tapioka konsumen bagi Petani Singkong Desa Rejosari Kecamatan Siak Kampar-Riau Universitas Riau, Pekan Baru.

Thoriq, A. dan A.Sutejo. 2017. Desain dan Uji Kinerja Pemarut Sagu Tipe TPB 01. Agritech Vol. 37 (4):453-461. 